\title{
Presentation with gastrointestinal symptoms and high case fatality associated with group $W$ meningococcal disease (MenW) in teenagers, England, July 2015 to January 2016
}

H Campbell ${ }^{1}$, SR Parikh ${ }^{1}$, R Borrow ${ }^{2}$, E Kaczmarski ${ }^{2}$, ME Ramsay ${ }^{1}$, SN Ladhani ${ }^{13}$

1. Immunisation Department, Public Health England, London United Kingdom

2. Meningococcal Reference Unit, Public Health England, Manchester United Kingdom

3. St. George's University of London, United Kingdom

Correspondence: Sydel R. Parikh (sydel.parikh@phe.gov.uk)

Citation style for this article:
Campbell H, Parikh SR, Borrow R, Kaczmarski E, Ramsay ME, Ladhani SN. Presentation with gastrointestinal symptoms and high case fatality associated with group W meningococcal disease (MenW) in teenagers, England, July 2015 to January 2016. Euro Surveill. 2016;21(12):pii=30175. DOI: http://dx.doi.org/10.2807/1560-7917. ES.2016.21.12.30175

Article submitted on 04 March 2016 / accepted on 24 March 2016 / published on 24 March 2016

Atypical clinical presentations associated with group W meningococcal disease (MenW) are well-described and include pneumonia, septic arthritis, endocarditis and epiglottitis/supraglottitis. Following anecdotal reports of teenagers presenting with predominantly gastrointestinal symptoms, we undertook a case review of MenW cases in 15 to 19 year-olds diagnosed in England between July 2015 and January 2016. Of the 15 cases, seven presented with a short history of nausea, vomiting and diarrhoea; five of these seven cases died within 24 hours of presentation to hospital.

The United Kingdom is currently experiencing a national outbreak of group $\mathrm{W}$ invasive meningococcal disease (IMD) due to rapid expansion of a single endemic hyper-virulent strain belonging to sequence type (ST) 11 clonal complex (cc) [1]. Group W IMD is associated with atypical clinical presentations, including pneumonia, septic arthritis, endocarditis and epiglottitis/ supraglottitis, mainly in older adults [2]. In early 2016, enhanced national surveillance conducted by Public Health England identified two fatal group W IMD cases in teenagers who presented with predominantly gastrointestinal symptoms, prompting a review of all 15 to 19 year-olds diagnosed with group W IMD in England in the current epidemiological year. Laboratory-confirmed cases were identified through national surveillance [1] and case records were rapidly reviewed on HPZone, a national web-based case management system used by health protection teams (HPTs) to record public health events and actions.

\section{Case series}

Between July 2015 and January 2016, 15 group W IMD cases were confirmed in previously-healthy 15 to 19 year-olds (9 females, 6 males), none of whom had received a meningococcal ACWY (MenACWY) conjugate vaccine. No direct epidemiological, temporal or spatial links between cases were identified. Nine cases were confirmed by culture and eight were serotyped as $\mathrm{W}: 2 \mathrm{a}$, a surrogate marker for the hyper-virulent ST-11 cc (Table). For each case, all available data in the public health and surveillance records were retrieved retrospectively and summarised in the Table.

Seven teenagers (6 females, 1 male) presented predominantly with an acute (24-48 hour) history of gastrointestinal symptoms (nausea, vomiting and/ or abdominal pain) together with or followed by diarrhoea in the 24 hours before attending hospital. Two cases were confirmed by blood culture and subsequently characterised as W:2a, a surrogate marker for the hyper-virulent ST-11 Cc; the other five were confirmed by PCR. Four of the seven patients had been reviewed either by their general practitioner (GP) or in the Accident and Emergency Department ( $A$ and $E$ ) on the first day $(n=3)$ or second day $(n=1)$ of illness and sent home with a diagnosis of gastroenteritis. A nonblanching rash at presentation, leading to a consideration of IMD in the differential diagnosis, was identified in only two of the seven teenagers after arrival in hospital. At least two patients were isolated in a side-room in $A$ and $E$ because of diarrhoea. Five of the seven teenagers died. One had collapsed at home and died in $A$ and $E$ despite initial successful resuscitation. Two died with a presumed diagnosis of 'gastrointestinal sepsis' and 'peritonitis' soon after presentation to $A$ and $E$ and before they could be transferred to intensive care unit (ICU), while two others died in the ICU within 24 hours of admission. All fatal cases had multi-organ failure. A post-mortem report in one case noted 'necrotic intestine, shocked lung and systemic sepsis'. Of the two 
Summary of histories of laboratory-confirmed cases of invasive meningococcal disease, as well as infecting strain and outcomes based on public health and surveillance records, England, July 2015-January 2016 (n=15)

\begin{tabular}{|c|c|c|c|c|c|c|}
\hline $\begin{array}{l}\text { History and clinical } \\
\text { features }\end{array}$ & Initial assessment ${ }^{\mathrm{a}}$ & $\begin{array}{l}\text { IMD } \\
\text { suspected }\end{array}$ & ICU & Outcome & Confirmation ${ }^{b}$ & Final diagnosis \\
\hline $\begin{array}{l}2 \text { days } D \text { and } V \text {, stomach } \\
\text { cramps lethargy, no rash }\end{array}$ & $\begin{array}{l}\text { Saw GP on Day } 1 \text { and sent home } \\
\text { with gastroenteritis diagnosis; } \\
\text { sudden deterioration Day } 2 \text { with } \\
\text { rapid progression in A and E; initially } \\
\text { diagnosed with abdominal sepsis }\end{array}$ & $\mathrm{N}$ & $\mathrm{N}$ & $\begin{array}{l}\text { Died in } A \\
\text { and } \mathrm{E}\end{array}$ & Blood culture & Septicaemia \\
\hline $\begin{array}{l}1 \text { day vomiting then } \\
\text { diarrhoea and sore } \\
\text { limbs; no rash }\end{array}$ & $\begin{array}{c}\text { Saw GP on Day 1, sent home with } \\
\text { gastroenteritis diagnosis; came to A } \\
\text { and E later same day }\end{array}$ & $\mathrm{N}$ & $\mathrm{N}$ & $\begin{array}{l}\text { Died in } A \\
\text { and } \mathrm{E}\end{array}$ & PCR blood & Septicaemia \\
\hline $\begin{array}{l}1 \text { day with } \mathrm{D} \text { and } \mathrm{V} \text {, } \\
\text { influenza-like illness, } \\
\text { and rapid deterioration }\end{array}$ & $\begin{array}{l}\text { Profoundly septic with seizures on } \\
\text { admission on Day } 1 \text {, then became } \\
\text { comatose }\end{array}$ & $\mathrm{N}$ & Y & $\begin{array}{c}\text { Died in ICU } \\
\text { next day }\end{array}$ & PCR blood & Septicaemia \\
\hline $\begin{array}{l}3 \text { days of } D \text { and } \\
V \text {, headache and } \\
\text { dehydration }\end{array}$ & $\begin{array}{l}\text { Went to } A \text { and } E \text { on Day 2, sent home } \\
\text { with gastroenteritis diagnosis; } \\
\text { returned next day with rapid } \\
\text { deterioration and multi-organ failure. }\end{array}$ & $\mathrm{N}$ & Y & $\begin{array}{l}\text { Died in ICU } \\
\text { same day }\end{array}$ & Blood culture & Septicaemia \\
\hline $\begin{array}{l}2 \text { days with headache } \\
\text { and vomiting followed by } \\
1 \text { day diarrhoea }\end{array}$ & $\begin{array}{c}\text { Found collapsed at home on Day } 3 \\
\text { and rushed to } A \text { and } E ; \text { p petechial rash } \\
\text { on back observed at } A \text { and } E \text {. }\end{array}$ & Y & $\mathrm{N}$ & \begin{tabular}{|c|} 
Cardiac \\
arrest in A \\
and E. Died.
\end{tabular} & PCR blood & Septicaemia \\
\hline $\begin{array}{l}1 \text { day } D \text { and } V \text {, feverc, } \\
\text { headache }\end{array}$ & $\begin{array}{c}\text { Hospital admission on Day 1; initial } \\
\text { blood culture and CSF meningococcal } \\
\text { PCR negative; developed rash after } \\
\text { hospital admission and blood sample } \\
\text { subsequently sent for PCR analysis } \\
\text { tested positive (reported } 12 \text { days } \\
\text { after onset) }\end{array}$ & $\mathrm{N}$ & Y & Survived & PCR blood & Septicaemia \\
\hline $\begin{array}{l}1 \text { day } \mathrm{D} \text { and } \mathrm{V} \text {, abdominal } \\
\text { pain }\end{array}$ & $\begin{array}{l}\text { Saw GP on Day 1, went to A and E } \\
\text { next day; hypotensive, tachycardic, } \\
\text { petechiae on face }\end{array}$ & Y & Y & Survived & PCR blood & Septicaemia \\
\hline $\begin{array}{l}\text { Generally unwell for } 1 \\
\text { week; feverc, short of } \\
\text { breath, general aches } \\
\text { (no rash) }\end{array}$ & $\begin{array}{l}\text { Presented to } A \text { and } E \text { with transient } \\
\text { ischaemic attacks, developed } \\
\text { pulmonary embolism }\end{array}$ & $\mathrm{N}$ & $\mathrm{N}$ & $\begin{array}{c}\text { Cardiac } \\
\text { arrest in A } \\
\text { and E. Died. }\end{array}$ & Blood culture & Septicaemia \\
\hline $\begin{array}{l}1 \text { day of fever }{ }^{c} \text {, mild } \\
\text { headache, nausea (no } \\
\text { rash) }\end{array}$ & $\begin{array}{c}\text { Admitted on Day } 1 \text { for } 24 \text { hours only; } \\
\text { diagnosis confirmed by blood culture } \\
\text { after discharge }\end{array}$ & $\mathrm{N}$ & $\mathrm{N}$ & Survived & Blood culture & Septicaemia \\
\hline $\begin{array}{l}2 \text { hours feverc, sore } \\
\text { throat, stiff neck and } \\
\text { headache, with purpuric } \\
\text { rash }\end{array}$ & $\begin{array}{c}\text { Presented directly to } A \text { and } E \text {, } \\
\text { admitted to ICU but improved within } \\
3 \text { days }\end{array}$ & Y & $\mathrm{N}$ & Survived & CSF culture & $\begin{array}{l}\text { Meningitis and } \\
\text { septicaemia }\end{array}$ \\
\hline $\begin{array}{l}\text { Feverc, neck pain, aches } \\
\text { - improved, then had } \\
\text { painful wrist joint } 3 \text { days } \\
\text { later }\end{array}$ & $\begin{array}{c}\text { Saw GP on Day } 4 \text { with painful wrist } \\
\text { and was referred to hospital; wrist } \\
\text { washed out }\end{array}$ & $\mathrm{N}$ & $\mathrm{N}$ & Survived & PCR joint fluid & Septic arthritis \\
\hline $\begin{array}{l}3 \text { days fever }{ }^{c} \text {, vomiting, } \\
\text { hip and elbow joint pain }\end{array}$ & $\begin{array}{l}\text { Admitted to hospital on Day } 4 \\
\text { and treated with IV antibiotics, no } \\
\text { orthopaedic intervention }\end{array}$ & $\mathrm{N}$ & $\mathrm{N}$ & Survived & Blood culture & Septic arthritis \\
\hline $\begin{array}{l}1 \text { day of fever }{ }^{c} \text {, malaise } \\
\text { and respiratory distress }\end{array}$ & $\begin{array}{c}\text { Radiologically confirmed pneumonia } \\
\text { on Day } 1\end{array}$ & $\mathrm{~N}$ & $\mathrm{~N}$ & Survived & Blood culture & Pneumonia \\
\hline $\begin{array}{l}2 \text { days feverc, headache, } \\
\text { coryza followed by } 1 \text { day } \\
\text { vomiting and coughing } \\
\text { blood }\end{array}$ & $\begin{array}{c}\text { Radiologically confirmed pneumonia } \\
\text { on Day } 3\end{array}$ & $\mathrm{~N}$ & $\mathrm{~N}$ & Survived & Blood culture & Pneumonia \\
\hline $\begin{array}{l}5 \text { days sore throat, } \\
\text { fatigue, lethargy, } \\
\text { lymphadenopathy; no } \\
\text { fever, no rash }\end{array}$ & $\begin{array}{c}\text { Seen at hospital on Day } 5 \text { and } \\
\text { blood cultures taken but was not } \\
\text { hospitalised; received ambulatory IV } \\
\text { antibiotics }\end{array}$ & $\mathrm{N}$ & $\mathrm{N}$ & Survived & Blood culture & Atypical \\
\hline
\end{tabular}

A and E: accidents and emergency department; CSF: cerebrospinal fluid; D and V: diarrhoea and vomiting; GP: general practitioner; IMD: invasive meningococcal disease; ICU: intensive care unit; IV: intravenous; N: no; NT: non typeable; PCR: polymerase chain reaction; Y: yes.

a Days are numbered from the day of symptom onset which is Day 1.

${ }^{b}$ All culture isolates were subsequently confirmed as W:2a, a surrogate marker for the hyper-virulent sequence type 11 clonal complex, apart from one patient with pneumonia (serotyped as NT/NT/NT).

c Temperature was not reported. 
patients who survived, both had short histories of vomiting and diarrhoea for less than 24 hours, went directly to $A$ and $E$ and were seriously unwell at presentation, requiring aggressive resuscitation and ICU admission.

Of the remaining eight cases (3 females, 5 males), seven cases were confirmed by blood $(n=6)$ or cerebrospinal fluid $(n=1)$ culture and six were subsequently characterised as $\mathrm{W}: 2 \mathrm{a}$, a surrogate marker for the hyper-virulent ST-11 cc; a blood culture from one patient with pneumonia was serotyped as NT/NT/NT. Among these eight individuals, two had the more characteristic clinical presentations of septicaemia - fever followed by rapid clinical deterioration (neither had a non-blanching rash) - and one died soon after presenting to $A$ and $E$. $A$ third teenager presented to $A$ and $E$ within hours of developing symptoms consistent with bacterial meningitis, was treated quickly and recovered without complications.

Four of the remaining five patients had other recognised 'atypical' presentations, including septic arthritis and pneumonia. The final case had non-specific symptoms lasting several days and no fever. This individual was managed with intravenous antibiotics in an ambulatory setting and blood cultures subsequently confirmed the diagnosis.

\section{Discussion}

Laboratory-confirmed group W IMD cases in England have increased from 19 cases in the 2008/09 epidemiological year to 176 cases in 2014/15, and its contribution to total IMD cases increased from $1.7 \%$ to $24 \%$ of all confirmed cases, respectively [3]. This increase has resulted from rapid expansion of a single endemic hyper-virulent strain belonging to ST $11 \mathrm{cc}$, which is also responsible for the ongoing group W IMD outbreak in Chile and other South American countries [4]. In August 2015, the United Kingdom (UK) introduced an adolescent MenACWY conjugate vaccination programme targeting 14 to 18 year-olds and new undergraduate university entrants [1].

The increase in group W IMD cases was communicated to clinical and public health colleagues through national briefing notes, peer-reviewed publications and online training materials (www.gov.uk/government/ collections/meningococcal-acwy-menacwy-vaccination-programme). These communications emphasised the high case fatality and intensive care admissions, and the well-described atypical clinical presentations - pneumonia, epiglottitis/supraglottitis and septic arthritis - seen in up to a quarter of cases [2].

Although nausea, vomiting and diarrhoea are welldescribed symptoms of meningococcal disease [5] and are included in most public awareness leaflets and websites (e.g. http://www.mrfpaediatricguide. info/diagnosis.php.html), IMD presentation with primarily gastrointestinal symptoms, whilst previously described, is rare $[6,7]$. An extensive review of the literature identified only one case report in 1999 in an 80 year-old woman who presented with fever, diarrhoea and abdominal pain; those authors, in turn, had only ascertained three previous cases in young adults in the literature [8]. Consequently, for the cases presented here, IMD was often not considered at first clinical assessment and public health actions, including chemoprophylaxis and vaccination, were, therefore, often delayed and by up to two weeks in one case. There were, however, no secondary cases identified among close contacts.

Interestingly, the unusual gastrointestinal presentation was also reported in the ongoing group W IMD outbreak in Chile, where 14 of 58 group W IMD cases (24\%) were initially diagnosed as gastroenteritis and eight of these 14 died [9]. Overall, diarrhoea was the only symptom that was over-represented among the 19 fatal cases ( $56 \%$ vs $27 \%, p=0.034$ ), most of whom died within a day of hospitalisation. Early diarrhoea and absence of fever are associated with poor prognosis in IMD, perhaps due to later recognition $[10,11]$.

We are currently following up all confirmed group W IMD cases in England and collecting more detailed clinical data from hospital records for cases presenting with predominantly gastrointestinal symptoms. We are aware of similar presentations in at least three young adults, suggesting that these findings are not confined to teenagers.

\section{Conclusion}

While atypical presentations such as septic arthritis, pneumonia, epiglottitis/supraglottitis and endocarditis are well-described for the less common meningococcal capsular groups ( $W$ and $Y$ ), clinical presentation with predominantly gastrointestinal symptoms - and diarrhoea, in particular - appears to be rare and currently associated with the hypervirulent ST-11 group W strain which, in teenagers at least, leads to rapidly progressive, severe disease and high case fatality. It is hoped that the adolescent MenACWY vaccination programme will help to control group W disease in the UK. In the meantime, as this hypervirulent strain is still spreading in South America and has now been reported in other European countries and Australia, it is important that frontline clinicians and public health specialists are aware of this unusual but severe presentation in order to provide appropriate safety net advice) [12], ensure prompt diagnosis and early treatment of cases, and timely chemoprophylaxis with vaccination for close contacts.

\section{Acknowledgements}

We would like to acknowledge the hard work of the surveillance team at PHE Colindale, the laboratory staff at PHE MRU and the Local Health Protection Teams. In particular we would like to thank Sonia Ribeiro, Kazim Beebeejaun, Steve Gray and Jay Lucidarme. 
None declared.

\section{Authors' contributions}

$\mathrm{HC}$ and SNL reviewed and summarised the case records. $\mathrm{HC}$ wrote the first draft of the manuscript. All authors reviewed and commented on the manuscript. All authors read and approved the final version.

\section{References}

1. Campbell H, Saliba V, Borrow R, Ramsay M, Ladhani SN. Targeted vaccination of teenagers following continued rapid endemic expansion of a single meningococcal group $\mathrm{W}$ clone (sequence type 11 clonal complex), United Kingdom 2015. Euro Surveill. 2015;20(28):21188. DOI: 10.2807/1560-7917. ES2015.20.28.21188 PMID: 26212140

2. Ladhani SN, Beebeejaun K, Lucidarme J, Campbell H, Gray $\mathrm{S}$, Kaczmarski E, et al. Increase in endemic Neisseria meningitidis capsular group W sequence type 11 complex associated with severe invasive disease in England and Wales. Clin Infect Dis. 2015;60(4):578-85. DOI: $10.1093 /$ cid/ciu881 PMID: 25389259

3. Ladhani SN, Ramsay M, Borrow R, Riordan A, Watson JM, Pollard AJ. Enter B and W: two new meningococcal vaccine programmes launched. Arch Dis Child. 2016;101(1):91-5. DOI: 10.1136/archdischild-2015-308928 PMID: 26672098

4. Lucidarme J, Hill DM, Bratcher HB, Gray SJ, du Plessis M, Tsang RS, et al. Genomic resolution of an aggressive, widespread, diverse and expanding meningococcal serogroup $B, C$ and W lineage. J Infect. 2015;71(5):544-52. DOI: 10.1016/j. jinf.2015.07.007 PMID: 26226598

5. Thompson MJ, Ninis N, Perera R, Mayon-White R, Phillips C, Bailey $L$, et al. Clinical recognition of meningococcal disease in children and adolescents. Lancet. 2006;367(9508):397-403. DOI: 10.1016/S0140-6736(06)67932-4 PMID: 16458763

6. Greenwood B. Meningococcal meningitis in Africa.Trans R Soc Trop Med Hyg. 1999;93(4):341-53. DOI: 10.1016/So0359203(99)90106-2 PMID: 10674069

7. Odegaard A. Unusual manifestations of meningococcal infection. A review.NIPH Ann. 1983;6(1):59-63.PMID: 6413905

8. Hussein A, Naschitz Y, Yeshurun D. [Fulminant meningococcemia presenting as a gastroenteritis-like syndrome]. Harefuah. 1999;137(9):371-2, 431. Hebrew.PMID: 11419036

9. Moreno G, López D, Vergara N, Gallegos D, Advis MF, Loayza S. Caracterización clínica de los casos de enfermedad meningocóccica por serogrupo W135 confirmados durante el año 2012 en Chile. [Clinical characterization of cases with meningococcal disease by W135 group in Chile, 2012]. Rev Chilena Infectol. 2013;30(4):350-60. Spanish.PMID: 24248103

10. Gedde-Dahl TW, Bjark P, Høiby EA, Høst JH, Bruun JN. Severity of meningococcal disease: assessment by factors and scores and implications for patient management.Rev Infect Dis. 1990;12(6):973-92. DOI: 10.1093/clinids/12.6.973 PMID: 2267493

11. Tønjum T, Nilsson F, Bruun JN, Haneberg B. The early phase of meningococcal disease.NIPH Ann. 1983;6(2):175-81.PMID: 6676683

12. Almond S, Mant D, Thompson M. Diagnostic safety-netting. Br J Gen Pract. 2009;59(568):872-4, discussion 874. DOI: 10.3399/ bjgpogX472971 PMID: 19861036

\section{License and copyright}

This is an open-access article distributed under the terms of the Creative Commons Attribution (CC BY 4.0) Licence. You may share and adapt the material, but must give appropriate credit to the source, provide a link to the licence, and indicate if changes were made.

This article is copyright of the authors, 2016. 